\title{
Pemberdayaan Usaha Binatu Lokasi Terdampak Eks-Lokalisasi Daerah Morokrembangan Surabaya
}

\author{
Radius Setiyawan ${ }^{1}$, Mahsun Jayadi ${ }^{2}$ \\ Universitas Muhammadiyah Surabaya \\ Email: radius.setiyawan@gmail.com ${ }^{1}$
}

\begin{abstract}
ABSTRAK
Pasca penutupan lokalisasi tanggal 12 Desember 2012 oleh Walikota Surabaya, Ada beberapa usaha binatu yang berdiri yang dikelola oleh mantan WTS (Wanita Tuna Susila). Usaha tersebut sudah berjalan 2 tahun akan tetapi ada beberapa kendala yang berarti sehingga usaha tersebut masih belum memampakkan hasil yang signifikan. Beberapa kendala yang dihadapi adalah: Managemen keuangan yang masih belum teratur sehingga masih sering tercampur antara uang pribadi dengan uang usaha, Model promosi yang masih sangan konvensional dan beberapa persoalan lain. Berdasarkan persoalan diatas maka solusi yang ditawarkan adalah sebagai berikut: (a) penambahan alat produksi sehingga mempercepat proses pengeringan dan meminimalisir ketergantungan terhadap cahaya matahari, (b) melatih membuat pembukuan yang efektif dan terkontrol, (c)melatih memcampur kimia Laundry yang tepat, dan (d) membuatkan model promosi yang kreatif dan berbasis teknologi. Dari hasil pemberdayaan diatas, maka terbukti terjadi perbaikan managemen dan mampu meningkatkan produktifitas usaha tersebut.
\end{abstract}

Kata Kunci : Kecamatan Krembangan, Mantan WTS, Usaha Binatu

\section{ABSTRACT}

After the closing of localization on December 12, 2012 by the Mayor of Surabaya, there are several stand-by laundry businesses run by former WTS (Women Tuna Susila). The business has been running for 2 years but there are some significant obstacles so the business still has not revealed significant results. Some of the obstacles faced are: Financial management that is still not regular so that is still often mixed between personal money with business money, promotion model is still conventional and some other problems. Based on the above problem, the solutions offered are as follows: (a) the addition of production equipment so as to speed up the drying process and minimize dependence on sunlight; (b) train effective and controlled bookkeeping; (c) train the proper Laundry chemistry; (d) create a creative and technology-based promotional model. From the results of the above empowerment, it proved to be an improvement of management and able to increase the productivity of the business.

Keywords: Krembangan Sub-district, Former WTS, Laundry Business

\section{PENDAHULUAN}

Surabaya sebagai salah satu kota industri dan pendidikan dengan aktivitas karyawan, mahasiswa maupun rumah tangga dengan pekerjaannya sibuk telah menciptakan peluang bisnis yang cukup menjanjikan dengan menawarkan jasa instannya yang mulai marak sekitar tahun 2000-an dengan bisnis pencucian pakaian atau lazim disebut laundry., kurang waktu dan menuntut untuk mendapatkan kemudahan, menjadi pendorong bagi pelaku bisnis Laundry untuk membuka usahanya. Bak cendawan 
di musim hujan dengan alasan pendukung lainnya bahwa dari objek usaha ini kondisi perekonomian yang lebih bagus pun menjadi alasan bagi menjamurnya usaha jasa Laundry ini.

Mentari Laundry merupakan UMKM yang berdiri sejak tahun 2013 awal, tepatnya pada bulan Desember 2012 Pemerintah Kota Surabaya menutup lokalisasi di kecamatan Krembangan Kota Surabaya. Adapun tempat yang dijadikan sebagai tempat lokalisasi adalah :

\begin{tabular}{|l|c|c|}
\hline \multicolumn{1}{|c|}{ LOKASI } & $\begin{array}{c}\text { JUMLAH } \\
\text { PENDUDUK }\end{array}$ & $\begin{array}{c}\text { JUMLAH PENDUDUK } \\
<17 \text { TAHUN }\end{array}$ \\
\hline RW 6 Kel. Krembangan (Lokalisasi Tambak Asri) & 18.761 Orang & 13.652 Orang \\
\hline RW 9 Kel. Krembangan (Lokalisasi Tambak Asri) & 2.578 Orang & 1.852 Orang \\
\hline RW 1 Kel. Sememi (Lokalisasi Sememi) & 8.056 Orang & 2.446 Orang \\
\hline RW 2 Kel. Klakah rejo (Lokalisasi Klakah Rejo) & 2.737 Orang & 731 Orang \\
\hline
\end{tabular}

Data Pemkot Surabaya, 2013

Penutupan lokalisasi tersebut mempunyai implikasi serius bagi para mantan Wanita Tuna Susila (WTS). Implikasi yang paling serius dan menjadi PR bagi pemerintah adalah persoalan hilangnya lapangan pekerjaan dan mengembalikan mereka untuk kembali hidup wajar kedalam lingkungan sosial yang lebih baik, oleh sebab itu, Pemerintah kota Surabaya berorientasi pada dua program untuk mereka dengan harapan ketika mereka lokalisasi sudah ditutup, mereka bisa hidup mandiri dan tidak lagi menjadi wanita tuna susila. Pasca penutupan, beberapa mantan WTS sudah mempunyai usaha sendiri. Apa yang dilakukan pemerintah kota Surabaya merupakan usaha untuk mengentaskan mereka dari kemiskinan. Oleh karena itu penyebutan kemiskinan dan ketertindasan lebih tepat menggunakan ungkapan "mustadh' afin kontemporer". Baidhawy (2009) membagi karakteristik mustadh'afin antara lain:

1. Mereka adalah individu dan atau kelompok sosial yang berada dalam posisi "minoritas" (qolil) baik secara kuantitatif dan atau kualitatif.

2. Mereka merupakan individu dan atau kelompok sosial yang menderita kerentanan terhadap penindasan terstruktur baik oleh kebijakan politik, ekonomi dan sosial (istidh'af).

3. Mereka dalah individu dan atau kelompok sosial yang belum terbebas dari rasa takut (khawf) dan karenanya juga tidak memiliki keberanian untuk melakukan perlawanan tehadap penindasan.

Bahaua (2008) menjelaskan bahwa masalah sosial yang dihadapi masyarakat Indonesia lebih banyak disebabkan oleh kemiskinan. Rumah Mentari Laundry adalah salah satu usaha yang dimiliki oleh mereka para mantan WTS. Hal tersebut adalah upaya mereduksi kemiskinan pada diri mereka. Usaha yang awal berdirinya mendapatkan modal dari pemerintah kota Surabaya sebagai kompensasi penutupan prostitusi. Dalam perjalanannya, Mentari Laundry mengalami berbagai persoalan karena ternyata mendirikan usaha lebih mudah dari pada menjaga keberlansungan usaha, disamping itu juga, perhatian pemerintah kota 
Surabaya tidak seperti diawal-awal pembubaran tempat prostitusi.

Mentari Laundry perhari ratarata dapat mencuci $60 \mathrm{~kg}$ cucian kotor, dengan harga bersaing $\mathrm{Rp}$ $4.000,-1 \quad>5 \quad \mathrm{~kg}$. Berdasarkan wawancara dengan pemilik binatu, konsumen seringkali kecewa karena ketepatan penyelesaian dan hal tersebut sering terjadi ketika di musim hujan yang berkepanjangan. Para konsumen sering kembali dengan tangan kosong mengingat baju yang mereka masukkan belum sepenuhnya kering dan bisa untuk diseterika.

\section{Profil Binaan}

Rumah Mentari Laundry berlokasi di Jl. Tambak Asri 147 Morokrembangan Surabaya ini sudah berjalan sekitar 2 tahun. Perhari ratarata mencuci $40 \mathrm{~kg}$ cucian kotor, dengan harga bersaing Rp 4.000,/>5kg. Pada akhir pekan bisa mencapai $60-90 \mathrm{~kg} / \mathrm{hari}$. Usaha ini merupakan usaha binatu yang hadir akibat dari paska pem

Berdasarkan hasil observasi, usaha tersebut menghadapi persoalan: (1). Mitra tidak biasa membedakan antara keuangan untuk bisnis dan keperluan rumah tangga. (2). Mitra masih sering berhutang pada rentenir. (3). Mitra tidak bisa mengatur keuangan untuk modal dan keuangan untuk karyawan (4). Kondisi workshop yang bercampur dengan rumah (5). Kondisi produksi yang tidak rapi

Tidak ada plakat identitas yang menunjukkan usaha laundry secara jelas dan (6). Kekurangan alat produksi karena mesin yang sudah ada sering mengalami kerusakan dan model Promosi yang konvensional.

\section{METODE PENELITIAN}

Metode yang digunakan dalam menunjang pelaksanaan program belajar terpadu yang berorientasi untuk menghasilkan wirausahawan yang memiliki gagasan baru dalam menciptakan lapangan kerja (job career). Maka pendekatan yang dilakukan adalah dengan menggunakan metode FGD (Focus Group Discussion) yaitu dengan melakukan diskusi bersama mitra usaha mikro kecil dan menengah (UMKM), mahasiswa magang beserta mentor dalam rangka menemu kenali masalah yang akan dihadapi dan mencari solusi secara bersama-sama dalam mengembangkan UMKM.

\section{Teknik operasional}

Teknik operasional yang akan dilakukan berdasarkan pada program yang akan dilakukan dan dicanangkan dengan harapan tujuan dan pelaksanaannya berjalan sebagaimana mestinya, maka langkah-langkah strategis yang akan dilakukan adalah sebagai berikut :
a. Melakukan koordinasi aktif pemilik usaha.
b. Melakukan pendekatan secara persuasif dengan mahasiswa yang akan diperbantukan di kedua Mitra.
c. Melakukan kerjasama dengan pihak lain dalam rangka


mendukung pelaksanaan program dan keberlanjutan program.

Dari hasil FGD, akhirnya dirumuskan beberapa program untuk mengatasi persoalan usaha.

\begin{tabular}{|c|c|c|}
\hline No & Program & Target \\
\hline 1 & $\begin{array}{l}\text { Perbaikan } \\
\text { Managemen } \\
\text { Keuangan dan } \\
\text { Managemen } \\
\text { Kerja }\end{array}$ & $\begin{array}{ll}\text { 1. } & \begin{array}{l}\text { Mitra memiliki } \\
\text { kemampuan } \\
\text { managemen } \\
\text { keuangan yang } \\
\text { strategis dan }\end{array} \\
\text { relevan } \\
\text { 2. } & \text { Mitra memiliki } \\
\text { alur produksi } \\
\text { yang sistematis }\end{array}$ \\
\hline 2 & $\begin{array}{l}\text { Perbaikan } \\
\text { Sarana }\end{array}$ & $\begin{array}{l}\text { Perbaikan Sarana } \\
\text { Produksi meliputi : } \\
\text { a. Tampilan } \\
\text { tempat usaha, } \\
\text { baik depan } \\
\text { maupun dalam } \\
\text { produksi } \\
\text { b. Papan } \\
\text { Informasi } \\
\text { loundri }\end{array}$ \\
\hline 3 & $\begin{array}{l}\text { Pemberian } \\
\text { alat Produksi } \\
\text { (Mesin Cuci) } \\
\text { dan Pelatihan } \\
\text { Marketing }\end{array}$ & $\begin{array}{ll}\text { 1. } & \begin{array}{l}\text { Pembuatan } \\
\text { paket jasa yang } \\
\text { menarik dan } \\
\text { terukur }\end{array} \\
\text { 2. } & \begin{array}{l}\text { Pemberian } \\
\text { Detergen alami } \\
\text { karya inovasi } \\
\text { mahasiswa. }\end{array} \\
\text { 3. } & \begin{array}{l}\text { Pembuatan } \\
\text { media sosial }\end{array} \\
\text { untuk promosi }\end{array}$ \\
\hline
\end{tabular}

\section{HASIL DAN PEMBAHASAN}

\section{Pelatihan Keuangan dan} Managemen Kerja

Pelatihan ini memiliki tujuan untuk meningkatkan kemampuan pembukuan keuangan. Persoalan utama dari binaan adalah masih susah membedakan antara keuangan pribadi dan keuangan usaha. Melaui pembukuan yang sederhana, mitra akan dipantau dan dievaluasi efektifitas pelatihan yang diberikan.
Selain itu juga, pelatihan tentang managemen kerja diberikan untuk mengatur pola kerja dan membedakan alur produksi agar lebih tersusun rapi.

Dari hasil pelatihan pertama, dilanjutkan dengan realisasi program perbaikan sarana. Perbaikan dilakukan dengan harapan memberikan kesan visual yang baik kepada customer/pelanggan. Perbaikan dilakukan dibagian luar maupun dalam usaha.

\section{Pemberian alat Produksi (Mesin Cuci) dan Pelatihan Paketing.}

Pemberian mesin cuci untuk meningkatkan produktifitas mitra dan membuatkan sistem paket pada produk (packeting system). Pembacaan akan segmentasi pelanggan melalui sistem paket atas produk akan meningkatkan pendapatan karena varian pelanggan akan merasa nyaman atas paket-paket yang disediakan. Hal ini merupakan bagian dari strategi pemasaran jasa bagi para pelanggan. Adapun beberapa hasil yang didapatkan setelah melakukan proses diskusi serta membaca persoalan yang dihadapi di kedua mitra adalah sebagai berikut:

a) Program member bagi para pelanggan tetap dengan memberikan potongan $20 \%$ per $35 \mathrm{Kg}$ dengan pembayaran di muka. paket ini berlaku untuk tiga bagian (Cuci Setrika, Setrika, Cuci Kering).

b) Reguler sistem ini berlaku untuk umum. 
c) Paket exsprees 3 jam (paket ini dilakukan untuk memberikan layanan prima terhadap pelanggan yang membutuhkan proses cuci cepat).

d) Tukar 10 nota dapat discount harga berlaku untuk regular.

e) Memberikan garansi cuci ulang apabila pelanggan tidak puas.

f) Jualan keliling yaitu waktunya ditentukan pada waktu pagi ketika awal sebelum buka diambil oleh piket shif 1 dan sore dilakukan oleh shif 2 .

g) Jemput barang dilakukan apabila ada pesanan dari pelanggan dan waktunya dibatasi dari jam kerja.

Hasil pendapatan 3 bulan terakhir:

\begin{tabular}{|c|c|c|}
\hline No & Bulan & Hasil \\
\hline 1 & Juni & 2.942 .000 \\
\hline 2 & Juli & 3.238 .500 \\
\hline 3 & Agustus & 3.800 .000 \\
\hline
\end{tabular}

Secara pendapatan, usaha binatu binaan mengalami peningkatan, terbukti dengan tabel diatas. Akan tetapi binaan masih menghadapi permasalahan sebagai berikut:

a) Tempat yang digunakan adalah rumah hasil kontrak, sehingga dalam hal pengelolaan mitra mengalami kesusahan terutama terkait daya listrik,

b) Tempat yang tidak strategis karena masuk kampung.

\section{SIMPULAN}

Kesimpulan yang didapat dari program binaan sebagai berikut:
1. Peningkatan pendapatan usaha binatu.

2. Adanya peningkatan kualitas SDM atas usaha pasca adanya pelatihan skill tentang managemen kerja dan keuangan.

3. Dalam rangka memberikan pelayanan prima maka penambahan fasilitas berupa mesin cuci sangat diperlukan untuk mendongkrak produktifitas usaha.

\section{DAFTAR PUSTAKA}

Anwar, 2007, Manajemen Pemberdayaan Perempuan : Perubahan sosial melalui Pembelajaran Vocational skills pada Keluarga Nelayan, Bandung : Alfabeta.

Bahua IM, 2008, Tinjauan Analitis Program Nasional Pemberdayaan Masyarakat (Pnpm) Mandiri Dalam Mengatasi Kemiskinan Di Era Otonomi Daerah. Http://eeqbal.blogspot.com/2008/1 2/tinjauan-analitis-programnasional.html., tanggal 09 Mei 2017.

Baidhawy, Zakiyuddin, 2009, Teologi Neo Al-Maun : Manifesto Islam menghadapi Globalisasi Kemiskinan Abad 21, Yogyakarta:Surya Sarana Grafika.

Chalil, Zaki Fuad (Sayed Mahdi ed.), 2009, Pemerataan Distribusi Kekayaan dalam ekonomi Islam, Jakarta : Erlangga.

Herjanto, Eddy, Manajemen Operasi, 2007, Grasindo, Jakarta.

Heizer, Jay and Barry Render, 2006, Operation Management, Prentice Hall, New Jersey. 